\title{
Editorial Note and Dedication
}

We have reached a milestone in the publication of the California Natural History Guides. Natural History of Vacant Lots is Volume 50 in this continuing series devoted to the flora, fauna, physical features, and environment of California and the West.

When this series was first proposed in the early 1950s, there were few publications available on California natural history other than technical works. Most of the popular books then available in California on natural history were written by Easterners about eastern species. I recall a book which supposedly covered the 100 most common native trees to be seen from coast to coast. The only native California species included was the Coast Redwood! A series of nature books used in California schools for many years was written and published in the Midwest. It treated primarily eastern species without mentioning that most of them did not occur in California. To find Cecropia moths the school children would need to travel east to Utah or north to Washington. To see Ruby-throated Hummingbirds they would have to go as far as Kansas, Oklahoma or Texas. Yet this editor, in 1926 as a fifth grader, was sent out by his teacher to find and collect Cecropia cocoons and to see and observe Ruby-throated Hummingbirds in the San Joaquin Valley. Forty years later, when my son reached the fifth grade in Hayward, he was given the identical assignment from the same books based on eastern plants and animals!

This lack of reliable, pertinent publications on California natural history for the nonscientist was recognized in the late 1920s by San Jose State Professors Gayle Pickwell and Karl Hazeltine. Each completed his graduate work at Cornell University where a tradition of writing and publishing popular natural history had long existed. There they came under the influence of famed naturalists A. A. Allen, J. G. Needham, E. L. Palmer, A. H. Wright, and others. 
In 1930 Gayle Pickwell and colleagues embarked on a program to provide information specifically on California natural history topics. Through 1935, under the series title Western Nature Study, they published books on birds, amphibians, wildflowers, trees, weather, and insects. These early natural history publications provided accurate and relevant California natural history information at a popular level for the first time.

The first concerted effort to provide broad coverage of California natural history began in 1959 with publication of the first guides in this series. By mid-1985, total sales for the series passed the one-million-copy mark. Most titles remain in print today and projected plans include at least another 50 titles. Today we are joined by a multitude of publishers and individuals producing many excellent natural history books. There is no longer a dearth of good California natural history information available to the general public!

I take great pleasure in joining authors Matt Vessel and Herb Wong in dedicating this fiftieth volume in the California Natural History Guide series to the memory of a group of dedicated naturalists and teachers who had a profound effect on the scope and development of field natural history in CaliforniaE. Laurence Palmer, Cornell University; and Gayle Pickwell, Karl Hazeltine, Carl D. Duncan, P. Victor Peterson, and Emily Smith of San Jose State College (now University).

Arthur C. Smith, General Editor California Natural History Guides 